Cellular Physiology
and Biochemistry and Biochemistry Published online: November 20, 2015

Accepted: November 05, 2015

This article is licensed under the Creative Commons Attribution-NonCommercial-NoDerivatives 4.0 International License (CC BY-NC-ND) (http://www.karger.com/Services/OpenAccessLicense). Usage and distribution for commercial purposes as well as any distribution of modified material requires written permission.

\title{
Licochalcone A Induced Suicidal Death of Human Erythrocytes
}

\author{
Jasmin Egler Florian Lang
}

Department of Physiology, University of Tübingen, Tübingen, Germany

\author{
Key Words \\ Phosphatidylserine $\cdot$ Cell volume $\bullet$ Eryptosis $•$ Oxidative stress $•$ Calcium
}

\begin{abstract}
Background: The anti-inflammatory, immunomodulatory, and antimicrobial Glycyrrhiza inflata extract component licochalcone A triggers apoptosis of tumor cells and is thus considered for the treatment of malignancy. Similar to apoptosis of nucleated cells, erythrocytes may enter eryptosis, the suicidal erythrocyte death characterized by cell shrinkage and cell membrane scrambling with phosphatidylserine translocation to the erythrocyte surface. Signaling involved in the triggering of eryptosis includes $\mathrm{Ca}^{2+}$ entry with increase of cytosolic $\mathrm{Ca}^{2+}$ activity $\left(\left[\mathrm{Ca}^{2+}\right]_{\mathrm{i}}\right)$, and ceramide. The present study explored, whether and how licochalcone A induces eryptosis. Methods: Human erythrocytes drawn from healthy individuals were exposed for 24 hours to $1-10 \mu \mathrm{g} / \mathrm{ml}$ licochalcone A. Flow cytometry was subsequently employed to estimate phosphatidylserine exposure at the cell surface from annexin $\mathrm{V}$ binding, cell volume from forward scatter, $\left[\mathrm{Ca}^{2+}\right]_{i}$ from Fluo3-fluorescence, and ceramide utilizing specific antibodies. In addition, hemolysis was quantified from hemoglobin release. Results: Licochalcone $A$ significantly increased the percentage of annexin-V-binding cells $(\geq 5 \mu \mathrm{g} / \mathrm{ml})$, significantly decreased forward scatter $(2.5-5 \mu \mathrm{g} / \mathrm{ml})$, significantly increased Fluo3-fluorescence $(\geq 7.5$ $\mu \mathrm{g} / \mathrm{ml})$, and significantly increased ceramide abundance $(10 \mu \mathrm{g} / \mathrm{ml})$. The effect of licochalcone on annexin-V-binding was not significantly modified, but hemolysis significantly enhanced by removal of extracellular $\mathrm{Ca}^{2+}$. Conclusions: Licochalcone triggers cell shrinkage and phospholipid scrambling of the erythrocyte cell membrane, an effect independent from $\mathrm{Ca}^{2+}$ entry and presumably in part due to ceramide.
\end{abstract}

\section{Introduction}

Licochalcone A, an anti-inflammatory [1-4], immunomodulatory [5, 6], and antimicrobial $[3,5,7-9]$ polyphenol extracted from Glycyrrhiza inflata $[1-3,10]$, triggers apoptosis or inhibits proliferation and migration of tumor cells [11], including those of cervical cancer [12], oral squamous carcinoma [7, 9, 13-15], esophageal carcinoma [16], gastric cancer [4, $17,18]$, hepatocellular carcinoma [2, 19], malignant pleural mesothelioma [20], bladder

Prof. Dr. Florian Lang

KARGER 125
Physiologisches Institut der Universität Tübingen

Gmelinstr. 5, D-72076 Tübingen (Germany)

Tel. +49 707129 72194, Fax. +49 707129 5618, E-Mail florian.lang@uni-tuebingen.de 
cancer [21, 22], prostate tumor [23-25]. ovarian carcinoma [26, 27], breast cancer [24], lung cancer [28] and leukemia [29]. Licochalcone A is thus considered for the treatment of malignancy $[12,30]$. Licochalcone A is partially effective by inducing oxidative stress $[17,19$, $21,26]$, mitochondrial depolarization [20,22], caspase activation $[13,14,25,26]$, inhibition of phosphatidylinositol 3-kinase (PI3K)/Akt/mammalian target of mTOR signaling [12, 25, $28,31]$, suppression of nuclear factor-kappa B (NF-kB) $[2,9]$, interaction with the Jak/Stat pathway [29], suppression of cyclooxygenase (COX)-2 expression [4, 31], and inhibition of cytochrome P450 (CYP) enzymes [32].

On the other hand, licochalcone A has been shown exert cytoprotective effects by decreasing oxidative stress [33]. Licochalcone B and licochalcone D have been shown to counteract apoptosis of cardiomyocytes [34-36], an effect involving inhibition of inflammation and oxidative stress, suppression of NF- $\mathrm{kB} / \mathrm{p} 65$ and p38 MAPK signaling and activation of the AKT pathway [35-37]. Licochalcone A is further effective against atopic dermatitis [38], asthma [39, 40], and osteoporosis [10, 41]. Licochalcone A further inhibits the liver $X$ receptor $\alpha$ and thus interferes with lipogenesis [37, 42-44].

Similar to licochalcone A, licochalcone F counteracts inflammation [45]. The proapoptotic and antitumor effect of licochalcone $A$ is shared by licochalcone $B[46,47]$ and $E[48,49]$, and the antimicrobial effect by licochalcone $\mathrm{E}$ [50].

Similar to apoptosis of nucleated cells, erythrocytes may enter eryptosis, the suicidal death of erythrocytes which is characterized by cell shrinkage and by phospholipid scrambling of the cell membrane leading to phosphatidylserine translocation to the cell surface [51]. Stimulators of eryptosis include energy depletion, increase of cytosolic $\mathrm{Ca}^{2+}$ activity $\left(\left[\mathrm{Ca}^{2+}\right]_{\mathrm{i}}\right)$, ceramide, caspases, casein kinase $1 \alpha$, Janus-activated kinase JAK3, protein kinase C, and p38 kinase [51]. Inhibitors of eryptosis include AMP activated kinase AMPK, cGMP-dependent protein kinase, PAK2 kinase and sorafenib/sunitinib sensitive kinases [51].

The present study explored whether licochalcone triggers eryptosis. To this end, human erythrocytes from healthy volunteers were treated with licochalcone and phosphatidylserine surface abundance, cell volume, $\left[\mathrm{Ca}^{2+}\right]_{i}$ and ceramide abundance determined by flow cytometry.

\section{Materials and Methods}

Erythrocytes, solutions and chemicals

Fresh Li-Heparin-anticoagulated blood samples were kindly provided by the blood bank of the University of Tübingen. The study is approved by the ethics committee of the University of Tübingen $(184 / 2003 \mathrm{~V})$. The blood was centrifuged at $120 \mathrm{~g}$ for $20 \mathrm{~min}$ at $21^{\circ} \mathrm{C}$ and the platelets and leukocytes-containing supernatant was disposed. Erythrocytes were incubated in vitro at a hematocrit of $0.4 \%$ in Ringer solution containing (in $\mathrm{mM}$ ) $125 \mathrm{NaCl}, 5 \mathrm{KCl}, 1 \mathrm{MgSO}_{4}, 32 \mathrm{~N}$-2-hydroxyethylpiperazine-N-2-ethanesulfonic acid (HEPES; pH 7.4), 5 glucose, 1 $\mathrm{CaCl}_{2}$, at $37^{\circ} \mathrm{C}$ for $24 \mathrm{~h}$. Where indicated, erythrocytes were exposed to licochalcone A (Sigma Aldrich, Hamburg, Germany) at the indicated concentrations.

\section{Annexin-V-binding and forward scatter}

After incubation under the respective experimental condition, $100 \mu \mathrm{l}$ cell suspension was washed in Ringer solution containing $5 \mathrm{mM} \mathrm{CaCl}_{2}$ and then stained with Annexin-V-FITC (1:200 dilution; ImmunoTools, Friesoythe, Germany) in this solution at $37^{\circ} \mathrm{C}$ for 20 min under protection from light. The annexin Vabundance at the erythrocyte surface was subsequently determined on a FACS Calibur (BD, Heidelberg, Germany). A dot plot of forward scatter (FSC) vs. side scatter (SSC) was set to linear scale for both parameters. The threshold of forward scatter was set at the default value of " 52 ".

\section{Hemolysis}

For the determination of hemolysis, the samples were centrifuged (10 min at $2000 \mathrm{rpm}$, room temperature) after incubation under the respective experimental conditions and the supernatants were harvested. As a measure of hemolysis, the hemoglobin $(\mathrm{Hb})$ concentration of the supernatant was 
Egler/Lang: Licochalcone-induced eryptosis

determined photometrically at $405 \mathrm{~nm}$. The absorption of the supernatant of erythrocytes lysed in distilled water was defined as $100 \%$ hemolysis.

Intracellular $\mathrm{Ca}^{2+}$

After incubation, erythrocytes were washed in Ringer solution and then loaded with Fluo-3/AM (Biotium, Hayward, USA) in Ringer solution containing $5 \mathrm{mM} \mathrm{CaCl}_{2}$ and $5 \mu \mathrm{M}$ Fluo-3/AM. The cells were incubated at $37^{\circ} \mathrm{C}$ for $30 \mathrm{~min}$ and washed once in Ringer solution containing $5 \mathrm{mM} \mathrm{CaCl}{ }_{2}$. The Fluo-3/AMloaded erythrocytes were resuspended in $200 \mu \mathrm{l}$ Ringer. Then, $\mathrm{Ca}^{2+}$-dependent fluorescence intensity was measured with an excitation wavelength of $488 \mathrm{~nm}$ and an emission wavelength of $530 \mathrm{~nm}$ on a FACS Calibur.

\section{Ceramide abundance}

To determine the ceramide abundance at the erythrocyte surface, a monoclonal antibody was used. After incubation, cells were stained for $1 \mathrm{~h}$ at $37^{\circ} \mathrm{C}$ with $1 \mu \mathrm{g} / \mathrm{ml}$ anti-ceramide antibody (clone MID 15B4; Alexis, Grünberg, Germany) in phosphate-buffered saline (PBS) containing $0.1 \%$ bovine serum albumin (BSA) at a dilution of 1:10. After two washing steps with PBS-BSA, cells were stained for 30 min with polyclonal fluorescein-isothiocyanate (FITC)-conjugated goat anti-mouse IgG and IgM specific antibody (BD Pharmingen, Hamburg, Germany) diluted 1:50 in PBS-BSA. Unbound secondary antibody was removed by repeated washing with PBS-BSA. Samples were then analyzed by flow cytometric analysis at an excitation wavelength of $488 \mathrm{~nm}$ and an emission wavelength of $530 \mathrm{~nm}$.

\section{Statistics}

Data are expressed as arithmetic means \pm SEM. As indicated in the figure legends, statistical analysis was made using ANOVA with Tukey's test as post-test and $t$ test as appropriate. $\mathrm{n}$ denotes the number of different erythrocyte specimens studied. Since different erythrocyte specimens used in distinct experiments may be differently susceptible to triggers of eryptosis, the same erythrocyte specimens have been used for control and experimental conditions.

\section{Results}

The present study addressed the putative effect of licochalcone on eryptosis, the suicidal erythrocyte death characterized by cell shrinkage and cell membrane scrambling with phosphatidylserine translocation to the cell surface. Phosphatidylserine exposing erythrocytes were identified utilizing annexin-V-binding which was quantified by flow cytometry. The erythrocytes were analysed following a 24 hours incubation in Ringer solution without or with licochalcone $(1-10 \mu \mathrm{g} / \mathrm{ml})$. As illustrated in Fig. 1, a 24 hours exposure to licochalcone increased the percentage of phosphatidylserine exposing erythrocytes, an effect reaching statistical significance at $5 \mu \mathrm{g} / \mathrm{ml}$ licochalcone.

In order to estimate erythrocyte volume, forward scatter was determined by flow cytometry. Again, the measurement was made after a 24 hours incubation in Ringer solution without or with licochalcone $(1-10 \mu \mathrm{g} / \mathrm{ml})$. As shown in Fig. 2, exposure of erythrocytes to 2.5 or $5 \mu \mathrm{g} / \mathrm{ml}$ licochalcone decreased erythrocyte forward scatter. No significant alterations of cell volume were observed at lower $(1 \mu \mathrm{g} / \mathrm{ml})$ and higher concentrations $(7.5$ and $10 \mu \mathrm{g} /$ $\mathrm{ml}$ of licochalcone.

Fluo3-fluorescence was taken as measure of cytosolic $\mathrm{Ca}^{2+}$ activity $\left(\left[\mathrm{Ca}^{2+}\right]_{\mathrm{i}}\right)$. As illustrated in Fig. 3, a 24 hours exposure to licochalcone increased the Fluo3-fluorescence, an effect reaching statistical significance at $7.5 \mu \mathrm{g} / \mathrm{ml}$ licochalcone.

In order to test whether licochalcone-induced translocation of phosphatidylserine or erythrocyte shrinkage required entry of extracellular $\mathrm{Ca}^{2+}$, erythrocytes were incubated for 24 hours in the absence or presence of 5 or $10 \mu \mathrm{g} / \mathrm{ml}$ licochalcone in the presence or nominal absence of extracellular $\mathrm{Ca}^{2+}$. As illustrated in Fig. 4, removal of extracellular $\mathrm{Ca}^{2+}$ did not significantly modify the effect of $5 \mu \mathrm{g} / \mathrm{ml}$ and $10 \mu \mathrm{g} / \mathrm{ml}$ licochalcone. Thus, licochalconeinduced cell membrane scrambling was not dependent on entry of extracellular $\mathrm{Ca}^{2+}$.

As shown in Fig. 5, following removal of extracellular $\mathrm{Ca}^{2+}, 5$ or $10 \mu \mathrm{g} / \mathrm{ml}$ licochalcone still tended to decrease forward scatter, an effect, however not reaching statistical sigificance. 


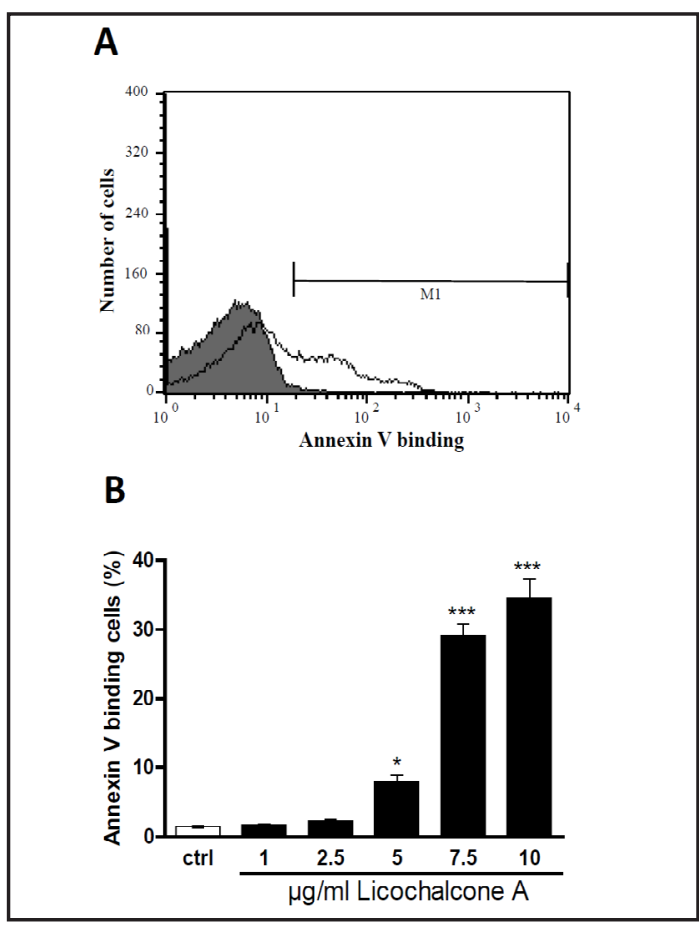

Fig. 1. Effect of licochalcone on phosphatidylserine exposure. A. Original histogram of annexin-Vbinding of erythrocytes following exposure for 24 hours to Ringer solution without (grey area) and with (black line) presence of $10 \mu \mathrm{g} / \mathrm{ml}$ licochalcone. B. Arithmetic means \pm SEM $(n=8)$ of erythrocyte annexin-V-binding (black bars) following incubation for 24 hours to Ringer solution without or with presence of licochalcone $(1-10 \mu \mathrm{g} / \mathrm{ml}) . *(p<0.05)$, $* * *(\mathrm{p}<0.001)$ indicates significant difference from the absence of licochalcone (ANOVA).

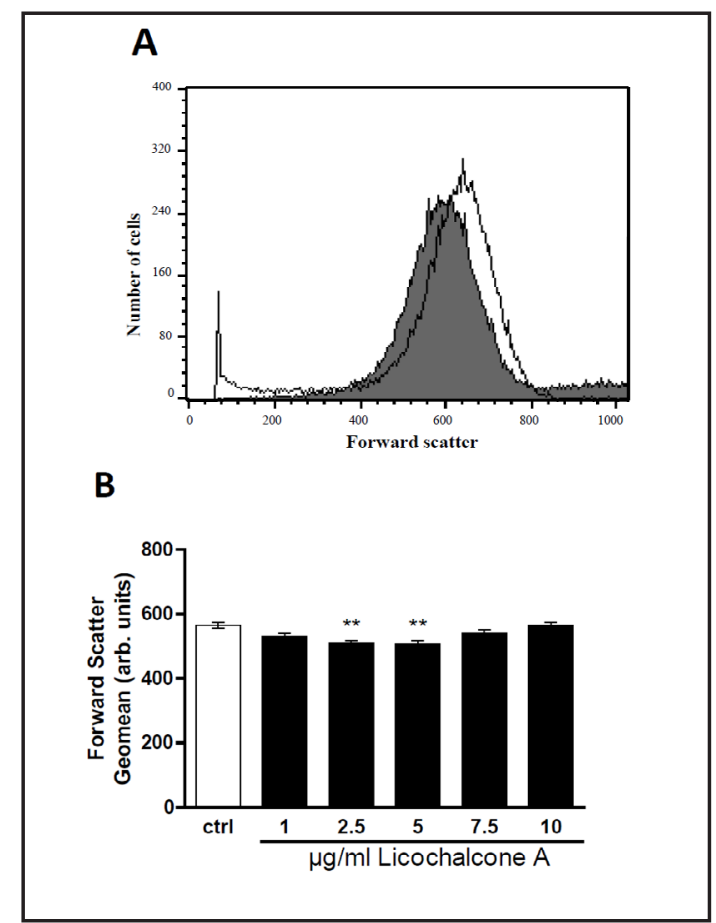

Fig. 2. Effect of licochalcone on erythrocyte forward scatter. A. Original histogram of forward scatter of erythrocytes following exposure for 24 hours to Ringer solution without (grey area) and with (black line) presence of $10 \mu \mathrm{g} / \mathrm{ml}$ licochalcone. B. Arithmetic means \pm SEM $(n=8)$ of the erythrocyte forward scatter (FSC) following incubation for 24 hours to Ringer solution without (white bar) or with (black bars) licochalcone $(1-10 \mu \mathrm{g} / \mathrm{ml}) .{ }^{* *}(\mathrm{p}<0.01)$ indicates significant difference from the absence of licochalcone (ANOVA).
Fig. 3. Effect of licochalcone on erythrocyte $\mathrm{Ca}^{2+}$ activity. A. Original histogram of Fluo3-fluorescence in erythrocytes following exposure for 24 hours to Ringer solution without (grey area) and with (black line) presence of licochalcone $(10 \mu \mathrm{g} / \mathrm{ml})$. B. Arithmetic means \pm SEM

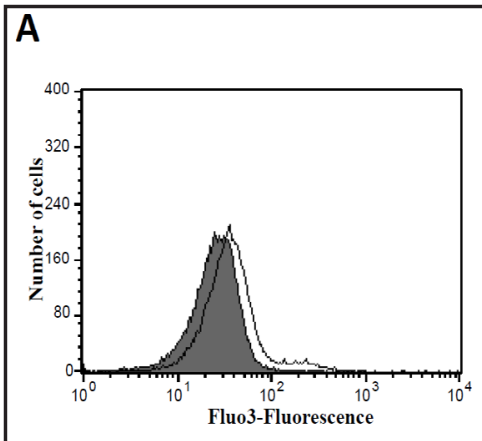
( $n=8$ ) of the Fluo3-fluorescence (arbitrary units) in erythrocytes exposed for 24 hours to Ringer solution without (white bar) or with (black bars) licochalcone $(1-10 \mu \mathrm{g} / \mathrm{ml}) .{ }^{* *}(\mathrm{p}<0.001)$ indicates significant difference from the absence of licochalcone (ANOVA).

In order to quantify hemolysis, the hemoglobin concentration in the supernatant was determined by photometry. As shown in Fig. 6, a 24 hours incubation with licochalcone increased the percentage of hemolysed erythrocytes. Removal of extracellular $\mathrm{Ca}^{2+}$ did not significantly modify the effect of $5 \mu \mathrm{g} / \mathrm{ml}$ licochalcone on hemolysis. However, removal of 


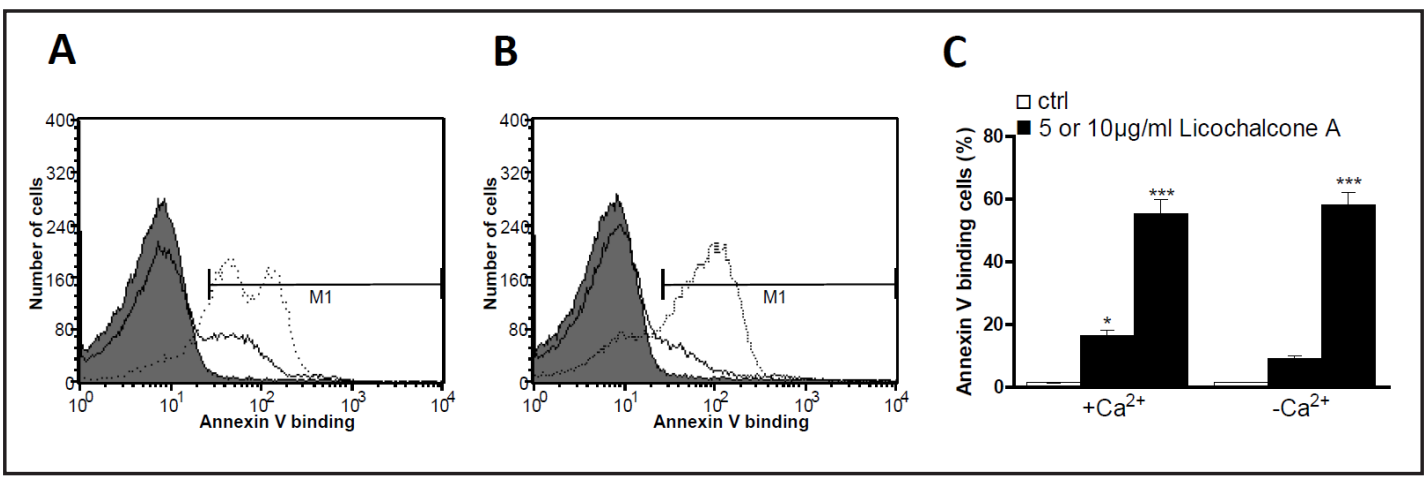

Fig. 4. $\mathrm{Ca}^{2+}$ insensitivity of licochalcone -induced phosphatidylserine exposure. A,B. Original histograms of annexin-V-binding of erythrocytes following exposure for 24 hours to Ringer solution without (grey area) and with (black line) presence of licochalcone $(5$ and $10 \mu \mathrm{g} / \mathrm{ml})$ in the presence (A) and absence (B) of extracellular $\mathrm{Ca}^{2+}$. C. Arithmetic means \pm SEM $(\mathrm{n}=8)$ of annexin-V-binding of erythrocytes after a 24 hours treatment with Ringer solution without (white bars) or with (black bars) licochalcone (5 or $10 \mu \mathrm{g} / \mathrm{ml}$ ) in the presence (left bars, $\left.+\mathrm{Ca}^{2+}\right)$ and absence (right bars, $\left.-\mathrm{Ca}^{2+}\right)$ of $\mathrm{Ca}^{2+} \cdot{ }^{*}(\mathrm{p}<0.05),{ }^{* * *}(\mathrm{p}<0.001)$ indicates significant difference from the absence of licochalcone.

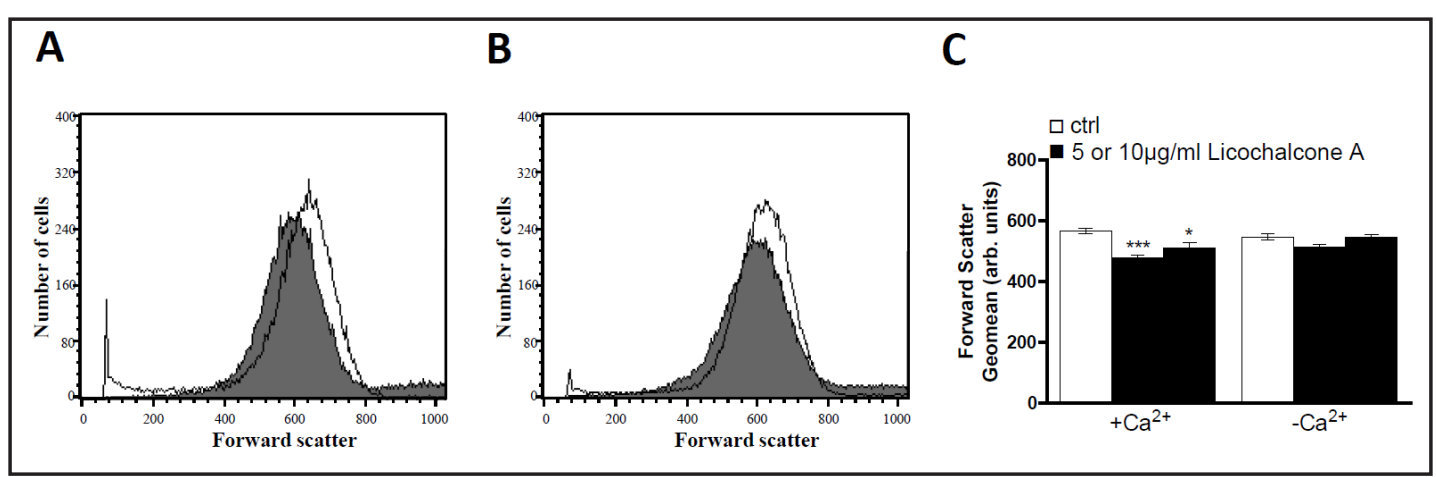

Fig. 5. Impact of $\mathrm{Ca}^{2+}$ removal on licochalcone - induced alterations of erythrocyte volume. A,B. Original histograms of erythrocyte forward scatter following exposure for 24 hours to Ringer solution without (grey areas) and with (black lines) presence of licochalcone $(10 \mu \mathrm{g} / \mathrm{ml})$ in the presence (A) and absence (B) of extracellular $\mathrm{Ca}^{2+}$. C. Arithmetic means \pm SEM $(n=8)$ of erythrocyte forward scatter after a 24 hours treatment with Ringer solution without (white bars) or with (black bars) licochalcone (5 or $10 \mu \mathrm{g} / \mathrm{ml}$ ) in the presence (left bars, $\left.+\mathrm{Ca}^{2+}\right)$ and absence (right bars, $\left.-\mathrm{Ca}^{2+}\right)$ of $\mathrm{Ca}^{2+} \cdot{ }^{*}(\mathrm{p}<0.05),{ }^{* * *}(\mathrm{p}<0.001)$ indicates significant difference from the absence of licochalcone.

Fig. 6. Impact of $\mathrm{Ca}^{2+}$ removal of licochalcone-induced hemolysis. Arithmetic means $\pm \operatorname{SEM}(n=4)$ of annexin-V-binding of erythrocytes after a 24 hours treatment with Ringer solution without (white bars) or with (black bars) licochalcone ( 5 or $10 \mu \mathrm{g} / \mathrm{ml}$ ) in the presence (left bars, $+\mathrm{Ca}^{2+}$ ) and absence (right bars, $\left.-\mathrm{Ca}^{2+}\right)$ of $\mathrm{Ca}^{2+} .{ }^{* * *}(\mathrm{p}<0.001)$ indicates significant difference from the absence of licochalcone, $\# \# \#(p<0.001)$ indicates significant difference from the presence of $\mathrm{Ca}^{2+}$ (ANOVA).

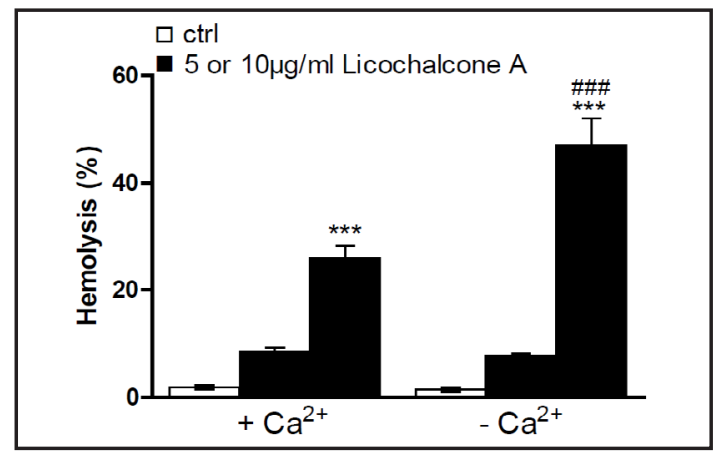

extracellular $\mathrm{Ca}^{2+}$ significantly augmented the stimulating effect of $10 \mu \mathrm{g} / \mathrm{ml}$ licochalcone on hemolysis.

$\mathrm{Ca}^{2+}$ independent triggers of eryptosis include ceramide. Thus, specific antibodies have been employed to quantify the ceramide abundance at the erythrocyte surface. As illustrated 


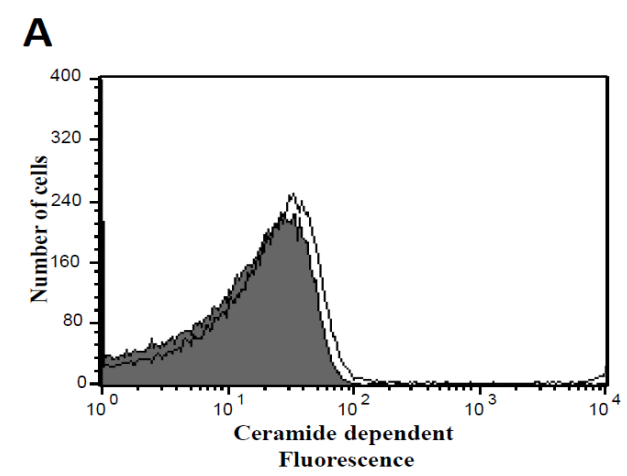

\section{B}

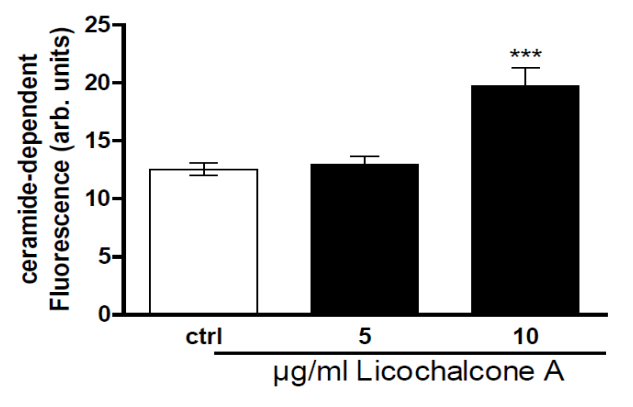

Fig. 7. Effect of licochalcone on erythrocyte ceramide abundance. A. Original histogram of ceramide abundance at the erythrocyte surface following exposure for 24 hours to Ringer solution without (grey area) and with (black line) presence of licochalcone $(10 \mu \mathrm{g} / \mathrm{ml})$. B. Arithmetic means \pm SEM $(\mathrm{n}=8)$ of the ceramide abundance (arbitrary units) at the erythrocyte surface following exposure for 24 hours to Ringer solution without (white bar) or with (black bars) licochalcone $(5$ and $10 \mu \mathrm{g} / \mathrm{ml}) .{ }^{* * *}(\mathrm{p}<0.001)$ indicates significant difference from the absence of licochalcone (ANOVA).

in Fig. 7, a 24 hours exposure to licochalcone $(10 \mu \mathrm{g} / \mathrm{ml})$ significantly increased the ceramide abundance.

\section{Discussion}

The present study discloses a novel effect of licochalcone, i.e. the triggering of suicidal erythrocyte death or eryptosis. Exposure of human erythrocytes to licochalcone results in cell shrinkage and cell membrane scrambling with phosphatidylserine translocation to the erythrocyte surface. The concentrations required for the effect are in the range of those required to induce apoptosis of tumor cells [17].

The effect of licochalcone on cell membrane scrambling and cell shrinkage was paralleled by increase of cytosolic $\mathrm{Ca}^{2+}$ activity $\left(\left[\mathrm{Ca}^{2+}\right]_{\mathrm{i}}\right) . \mathrm{Ca}^{2+}$ entry from the extracellular space appears not to be required, however, for the effect of licochalcone on cell membrane scrambling. Removal of extracellular $\mathrm{Ca}^{2+}$ disrupted, however, the licochalcone induced cell shrinkage. An increase of $\left[\mathrm{Ca}^{2+}\right]_{\mathrm{i}}$ activates $\mathrm{Ca}^{2+}$ sensitive $\mathrm{K}^{+}$channels which contributes to or even accounts for the cell shrinkage due to $\mathrm{K}^{+}$exit, cell membrane hyperpolarization, $\mathrm{Cl}^{-}$exit and thus cellular loss of $\mathrm{KCl}$ with water [52]. Following an increase of licochalcone concentration to 7.5 or $10 \mu \mathrm{g} /$ $\mathrm{ml}$ the licochalcone induced cell shrinkage disappeared despite an increasing $\left[\mathrm{Ca}^{2+}\right]_{\mathrm{i}}$. Possibly, licochalcone has a dual effect on erythrocyte cell volume, $\mathrm{Ca}^{2+}$ dependent cell shrinkage and a $\mathrm{Ca}^{2+}$ independent cell swelling. Possibly due to the latter effect, licochalcone triggers hemolysis, an effect augmented by removal of extracellular $\mathrm{Ca}^{2+}$. It is actually the purpose of the $\mathrm{Ca}^{2+}$ sensitive $\mathrm{K}^{+}$channels to counteract swelling of defective erythrocytes [51]. The phosphatidylserine exposure is followed by rapid clearance of the defective erythrocytes from circulating blood [51]. The preceding eryptosis is thus supposed to prevent hemolysis. The hemolysis would otherwise lead to release of hemoglobin, which is filtered in renal glomerula, precipitates in the acidic lumen of renal tubules and thus occludes nephrons [53].

Excessive eryptosis may, on the other hand, lead to anemia, if the formation of new erythrocytes cannot match the loss of eryptotic erythrocytes [51]. Phosphatidylserine exposing erythrocytes further adhere to the vascular wall [54], stimulate blood clotting and trigger thrombosis [55-57]. Thus, triggering of eryptosis may impair microcirculation [55, 58-62].

It is expected that the sensitivity to the eryptotic effect of licochalcone is increased by clinical conditions associated with enhanced eryptosis, such as dehydration [63],

\section{KARGER}


hyperphosphatemia [64] chronic kidney disease (CKD) [65-68], hemolytic-uremic syndrome [69], diabetes [70], hepatic failure [71], malignancy [51], sepsis [72], sickle-cell disease, beta-thalassemia, Hb-C and G6PD-deficiency [51], as well as Wilsons disease [73]. In those disorders lower licochalcone concentrations may be sufficient to trigger eryptosis. Moreover, eryptosis is stimulated by a wide variety of xenobiotics [63, 64, 66, 74-96]. Combination of licochalcone with those xenobiotics may lead to additive effects.

In conclusion, licochalcone triggers eryptosis with cell shrinkage and cell membrane scrambling, an effect not depending on $\mathrm{Ca}^{2+}$ activity but paralleled by and presumably in part due to increased ceramide abundance.

\section{Acknowledgements}

The authors acknowledge the meticulous preparation of the manuscript by Tanja Loch. The study was supported by the Deutsche Forschungsgemeinschaft and Open Access Publishing Fund of Tuebingen University.

\section{Disclosure Statement}

The authors of this manuscript state that they do not have any conflict of interests and nothing to disclose.

\section{References}

1 Dunlap TL, Wang S, Simmler C, Chen SN, Pauli GF, Dietz BM, Bolton JL: Differential Effects of Glycyrrhiza Species on Genotoxic Estrogen Metabolism: Licochalcone A Downregulates P450 1B1, whereas Isoliquiritigenin Stimulates It. Chem Res Toxicol 2015;28:1584-1594.

2 Tsai JP, Hsiao PC, Yang SF, Hsieh SC, Bau DT, Ling CL, Pai CL, Hsieh YH: Licochalcone A suppresses migration and invasion of human hepatocellular carcinoma cells through downregulation of MKK4/JNK via NFkappaB mediated urokinase plasminogen activator expression. PLoS One 2014; 9:e86537.

3 Zhao H, Jiang JT, Zheng QS: [Advance in studies on pharmacological effects of licochalcone A]. Zhongguo Zhong Yao Za Zhi 2013;38:3814-3818.

4 Park JM, Park SH, Hong KS, Han YM, Jang SH, Kim EH, Hahm KB: Special licorice extracts containing lowered glycyrrhizin and enhanced licochalcone A prevented Helicobacter pylori-initiated, salt dietpromoted gastric tumorigenesis. Helicobacter 2014;19:221-236.

5 Feldman M, Grenier D: Cranberry proanthocyanidins act in synergy with licochalcone A to reduce Porphyromonas gingivalis growth and virulence properties, and to suppress cytokine secretion by macrophages. J Appl Microbiol 2012;113:438-447.

6 Fontes LB, Dos Santos Dias D, de Carvalho LS, Mesquita HL, da Silva Reis L, Dias AT, Da Silva Filho AA, do Amaral Correa JO: Immunomodulatory effects of licochalcone A on experimental autoimmune encephalomyelitis. J Pharm Pharmacol 2014;66:886-894.

7 Kim JS, Park MR, Lee SY, Kim do K, Moon SM, Kim CS, Cho SS, Yoon G, Im HJ, You JS, Oh JS, Kim SG: Licochalcone A induces apoptosis in KB human oral cancer cells via a caspase-dependent FasL signaling pathway. Oncol Rep 2014;31:755-762.

8 Hao H, Hui W, Liu P, Lv Q, Zeng X, Jiang H, Wang Y, Zheng X, Zheng Y, Li J, Zhou X, Jiang Y: Effect of licochalcone A on growth and properties of Streptococcus suis. PLoS One 2013;8:e67728.

9 Shen H, Zeng G, Tang G, Cai X, Bi L, Huang C, Yang Y: Antimetastatic effects of licochalcone A on oral cancer via regulating metastasis-associated proteases. Tumour Biol 2014;35:7467-7474.

10 Shang F, Ming L, Zhou Z, Yu Y, Sun J, Ding Y, Jin Y: The effect of licochalcone A on cell-aggregates ECM secretion and osteogenic differentiation during bone formation in metaphyseal defects in ovariectomized rats. Biomaterials 2014;35:2789-2797.

11 Yao K, Chen H, Lee MH, Li H, Ma W, Peng C, Song NR, Lee KW, Bode AM, Dong Z, Dong Z: Licochalcone A, a natural inhibitor of c-Jun N-terminal kinase 1. Cancer Prev Res (Phila) 2014;7:139-149. 


\section{Cellular Physiology Cell Physiol Biochem 2015;37:2060-2070 \begin{tabular}{l|l|l|l} 
DOI: 10.1159/000438565 & (c) 2015 The Author(s). Published by S. Karger AG, Basel \\
www.karger.com/cpb
\end{tabular}}

Egler/Lang: Licochalcone-induced eryptosis

12 Tsai JP, Lee CH, Ying TH, Lin CL, Lin CL, Hsueh JT, Hsieh YH: Licochalcone A induces autophagy through $\mathrm{PI} 3 \mathrm{~K} / \mathrm{Akt} / \mathrm{mTOR}$ inactivation and autophagy suppression enhances Licochalcone A-induced apoptosis of human cervical cancer cells. Oncotarget 2015;

13 Cho JJ, Chae JI, Yoon G, Kim KH, Cho JH, Cho SS, Cho YS, Shim JH: Licochalcone A, a natural chalconoid isolated from Glycyrrhiza inflata root, induces apoptosis via Sp1 and Sp1 regulatory proteins in oral squamous cell carcinoma. Int J Oncol 2014;45:667-674.

14 Zeng G, Shen H, Yang Y, Cai X, Xun W: Licochalcone A as a potent antitumor agent suppresses growth of human oral cancer SCC-25 cells in vitro via caspase-3 dependent pathways. Tumour Biol 2014;35:65496555.

15 Park MR, Kim SG, Cho IA, Oh D, Kang KR, Lee SY, Moon SM, Cho SS, Yoon G, Kim CS, Oh JS, You JS, Kim do $\mathrm{K}$, Seo YS, Im HJ, Kim JS: Licochalcone-A induces intrinsic and extrinsic apoptosis via ERK1/2 and p38 phosphorylation-mediated TRAIL expression in head and neck squamous carcinoma FaDu cells. Food Chem Toxicol 2015;77:34-43.

16 Yang P, Tuo L, Wu Q Cao X: Licochalcone-A sensitizes human esophageal carcinoma cells to TRAILmediated apoptosis by proteasomal degradation of XIAP. Hepatogastroenterology 2014;61:1229-1234.

17 Hao W, Yuan X, Yu L, Gao C, Sun X, Wang D, Zheng Q: Licochalcone A-induced human gastric cancer BGC823 cells apoptosis by regulating ROS-mediated MAPKs and PI3K/AKT signaling pathways. Sci Rep 2015;5:10336.

18 Xiao XY, Hao M, Yang XY, Ba Q, Li M, Ni SJ, Wang LS, Du X: Licochalcone A inhibits growth of gastric cancer cells by arresting cell cycle progression and inducing apoptosis. Cancer Lett 2011;302:69-75.

19 Choi AY, Choi JH, Hwang KY, Jeong YJ, Choe W, Yoon KS, Ha J, Kim SS, Youn JH, Yeo EJ, Kang I: Licochalcone A induces apoptosis through endoplasmic reticulum stress via a phospholipase Cgamma1-, $\mathrm{Ca}(2+)-$, and reactive oxygen species-dependent pathway in HepG2 human hepatocellular carcinoma cells. Apoptosis 2014;19:682-697.

20 Kim KH, Yoon G, Cho JJ, Cho JH, Cho YS, Chae JI, Shim JH: Licochalcone A induces apoptosis in malignant pleural mesothelioma through downregulation of Sp1 and subsequent activation of mitochondria-related apoptotic pathway. Int J Oncol 2015;46:1385-1392.

21 Jiang J, Yuan X, Zhao H, Yan X, Sun X, Zheng Q: Licochalcone A inhibiting proliferation of bladder cancer T24 cells by inducing reactive oxygen species production. Biomed Mater Eng 2014;24:1019-1025.

22 Yuan X, Li D, Zhao H, Jiang J, Wang P, Ma X, Sun X, Zheng Q: Licochalcone A-induced human bladder cancer T24 cells apoptosis triggered by mitochondria dysfunction and endoplasmic reticulum stress. Biomed Res Int 2013;2013:474272.

23 Fu Y, Hsieh TC, Guo J, Kunicki J, Lee MY, Darzynkiewicz Z, Wu JM: Licochalcone-A, a novel flavonoid isolated from licorice root (Glycyrrhiza glabra), causes G2 and late-G1 arrests in androgen-independent PC-3 prostate cancer cells. Biochem Biophys Res Commun 2004;322:263-270.

24 Rafi MM, Rosen RT, Vassil A, Ho CT, Zhang H, Ghai G, Lambert G, DiPaola RS: Modulation of bcl-2 and cytotoxicity by licochalcone-A, a novel estrogenic flavonoid. Anticancer Res 2000;20:2653-2658.

25 Yo YT, Shieh GS, Hsu KF, Wu CL, Shiau AL: Licorice and licochalcone-A induce autophagy in LNCaP prostate cancer cells by suppression of Bcl-2 expression and the mTOR pathway. J Agric Food Chem 2009;57:82668273.

26 Kim YJ, Jung EB, Myung SC, Kim W, Lee CS: Licochalcone A enhances geldanamycin-induced apoptosis through reactive oxygen species-mediated caspase activation. Pharmacology 2013;92:49-59.

27 Lee CS, Kwak SW, Kim YJ, Lee SA, Park ES, Myung SC, Kim W, Lee MS, Lee JJ: Guanylate cyclase activator YC-1 potentiates apoptotic effect of licochalcone A on human epithelial ovarian carcinoma cells via activation of death receptor and mitochondrial pathways. Eur J Pharmacol 2012;683:54-62.

28 Huang HC, Tsai LL, Tsai JP, Hsieh SC, Yang SF, Hsueh JT, Hsieh YH: Licochalcone A inhibits the migration and invasion of human lung cancer cells via inactivation of the Akt signaling pathway with downregulation of MMP-1/-3 expression. Tumour Biol 2014;35:12139-12149.

29 Funakoshi-Tago M, Tago K, Nishizawa C, Takahashi K, Mashino T, Iwata S, Inoue H, Sonoda Y, Kasahara T: Licochalcone A is a potent inhibitor of TEL-Jak2-mediated transformation through the specific inhibition of Stat3 activation. Biochem Pharmacol 2008;76:1681-1693.

30 Park SY, Kim EJ, Choi HJ, Seon MR, Lim SS, Kang YH, Choi MS, Lee KW, Yoon Park JH: Anti-carcinogenic effects of non-polar components containing licochalcone A in roasted licorice root. Nutr Res Pract 2014;8:257-266. 


\section{Cellular Physiology Cell Physiol Biochem 2015;37:2060-2070 \begin{tabular}{l|l|l} 
DOI: 10.1159/000438565 & (c) 2015 The Author(s). Published by S. Karger AG, Basel \\
wiochw.karger.com/cpb
\end{tabular}}

Egler/Lang: Licochalcone-induced eryptosis

31 Song NR, Kim JE, Park JS, Kim JR, Kang H, Lee E, Kang YG, Son JE, Seo SG, Heo YS, Lee KW: Licochalcone A, a polyphenol present in licorice, suppresses UV-induced COX-2 expression by targeting PI3K, MEK1, and B-Raf. Int J Mol Sci 2015;16:4453-4470.

32 He W, Wu JJ, Ning J, Hou J, Xin H, He YQ, Ge GB, Xu W: Inhibition of human cytochrome P450 enzymes by licochalcone A, a naturally occurring constituent of licorice. Toxicol In Vitro 2015;29:1569-1576.

33 Kuhnl J, Roggenkamp D, Gehrke SA, Stab F, Wenck H, Kolbe L, Neufang G: Licochalcone A activates Nrf2 in vitro and contributes to licorice extract-induced lowered cutaneous oxidative stress in vivo. Exp Dermatol 2015;24:42-47.

34 Han J, Wang D, Yu B, Wang Y, Ren H, Zhang B, Wang Y, Zheng Q: Cardioprotection against ischemia/ reperfusion by licochalcone B in isolated rat hearts. Oxid Med Cell Longev 2014;2014:134862.

35 Yuan X, Niu HT, Wang PL, Lu J, Zhao H, Liu SH, Zheng QS, Li CG: Cardioprotective Effect of Licochalcone D against Myocardial Ischemia/Reperfusion Injury in Langendorff-Perfused Rat Hearts. PLoS One 2015;10:e0128375.

36 Zhou M, Liu L, Wang W, Han J, Ren H, Zheng Q, Wang D: Role of licochalcone C in cardioprotection against ischemia/reperfusion injury of isolated rat heart via antioxidant, anti-inflammatory, and anti-apoptotic activities. Life Sci 2015;132:27-33.

37 Han JY, Park SH, Yang JH, Kim MG, Cho SS, Yoon G, Cheon SH, Ki SH: Licochalcone Suppresses LXRalphaInduced Hepatic Lipogenic Gene Expression through AMPK/Sirt1 Pathway Activation. Toxicol Res 2014;30:19-25.

38 Wananukul S, Chatproedprai S, Chunharas A, Limpongsanuruk W, Singalavanija S, Nitiyarom R, Wisuthsarewong W: Randomized, double-blind, split-side, comparison study of moisturizer containing licochalcone A and 1\% hydrocortisone in the treatment of childhood atopic dermatitis. J Med Assoc Thai 2013;96:1135-1142.

39 Chu X, Jiang L, Wei M, Yang X, Guan M, Xie X, Wei J, Liu D, Wang D: Attenuation of allergic airway inflammation in a murine model of asthma by Licochalcone A. Immunopharmacol Immunotoxicol 2013;35:653-661.

40 Kim SH, Yang M, Xu JG, Yu X, Qian XJ: Role of licochalcone A on thymic stromal lymphopoietin expression: implications for asthma. Exp Biol Med (Maywood) 2015;240:26-33.

41 Ming L, Jin F, Huang P, Luo H, Liu W, Zhang L, Yuan W, Zhang Y, Jin Y: Licochalcone A up-regulates of FasL in mesenchymal stem cells to strengthen bone formation and increase bone mass. Sci Rep 2014;4:7209.

42 Oh GS, Lee GG, Yoon J, Oh WK, Kim SW: Selective inhibition of liver X receptor alpha-mediated lipogenesis in primary hepatocytes by licochalcone A. Chin Med 2015;10:8.

43 Quan HY, Baek NI, Chung SH: Licochalcone A prevents adipocyte differentiation and lipogenesis via suppression of peroxisome proliferator-activated receptor gamma and sterol regulatory element-binding protein pathways. J Agric Food Chem 2012;60:5112-5120.

44 Quan HY, Kim SJ, Kim do Y, Jo HK, Kim GW, Chung SH: Licochalcone A regulates hepatic lipid metabolism through activation of AMP-activated protein kinase. Fitoterapia 2013;86:208-216.

45 Bak EJ, Choi KC, Jang S, Woo GH, Yoon HG, Na Y, Yoo YJ, Lee Y, Jeong Y, Cha JH: Licochalcone F alleviates glucose tolerance and chronic inflammation in diet-induced obese mice through Akt and p38 MAPK. Clin Nutr 2015;10.1016/j.clnu.2015.03.005

46 Yuan X, Li T, Xiao E, Zhao H, Li Y, Fu S, Gan L, Wang Z, Zheng Q Wang Z: Licochalcone B inhibits growth of bladder cancer cells by arresting cell cycle progression and inducing apoptosis. Food Chem Toxicol 2014;65:242-251.

47 Zhao H, Yuan X, Jiang J, Wang P, Sun X, Wang D, Zheng Q: Antimetastatic effects of licochalcone B on human bladder carcinoma T24 by inhibition of matrix metalloproteinases- 9 and NF-small ka, CyrillicB activity. Basic Clin Pharmacol Toxicol 2014;115:527-533.

48 Chang HJ, Yoon G, Park JS, Kim MH, Baek MK, Kim NH, Shin BA, Ahn BW, Cheon SH, Jung YD: Induction of apoptosis by the licochalcone $\mathrm{E}$ in endothelial cells via modulation of NF-kappaB and Bcl-2 Family. Biol Pharm Bull 2007;30:2290-2293.

49 Kwon SJ, Park SY, Kwon GT, Lee KW, Kang YH, Choi MS, Yun JW, Jeon JH, Jun JG, Park JH: Licochalcone E present in licorice suppresses lung metastasis in the 4T1 mammary orthotopic cancer model. Cancer Prev Res (Phila) 2013;6:603-613.

50 Zhou T, Deng X, Qiu J: Antimicrobial activity of licochalcone E against Staphylococcus aureus and its impact on the production of staphylococcal alpha-toxin. J Microbiol Biotechnol 2012;22:800-805. 


\section{Cellular Physiology Cell Physiol Biochem 2015;37:2060-2070

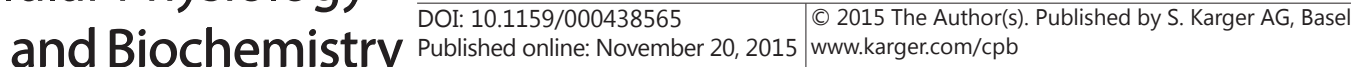

Egler/Lang: Licochalcone-induced eryptosis

51 Lang E, Qadri SM, Lang F: Killing me softly - suicidal erythrocyte death. Int J Biochem Cell Biol 2012;44:1236-1243.

52 Lang PA, Kaiser S, Myssina S, Wieder T, Lang F, Huber SM: Role of Ca2+-activated K+ channels in human erythrocyte apoptosis. Am J Physiol Cell Physiol 2003;285:C1553-C1560.

53 Harrison HE, Bunting H, Ordway NK, Albrink WS: The Pathogenesis of the Renal Injury Produced in the Dog by Hemoglobin or Methemoglobin. J Exp Med 1947;86:339-356.

54 Borst O, Abed M, Alesutan I, Towhid ST, Qadri SM, Foller M, Gawaz M, Lang F: Dynamic adhesion of eryptotic erythrocytes to endothelial cells via CXCL16/SR-PSOX. Am J Physiol Cell Physiol 2012;302:C644-C651.

55 Andrews DA, Low PS: Role of red blood cells in thrombosis. Curr Opin Hematol 1999;6:76-82.

56 Chung SM, Bae ON, Lim KM, Noh JY, Lee MY, Jung YS, Chung JH: Lysophosphatidic acid induces thrombogenic activity through phosphatidylserine exposure and procoagulant microvesicle generation in human erythrocytes. Arterioscler Thromb Vasc Biol 2007;27:414-421.

57 Zwaal RF, Comfurius P, Bevers EM: Surface exposure of phosphatidylserine in pathological cells. Cell Mol Life Sci 2005;62:971-988.

58 Abed M, Towhid ST, Mia S, Pakladok T, Alesutan I, Borst O, Gawaz M, Gulbins E, Lang F: Sphingomyelinaseinduced adhesion of eryptotic erythrocytes to endothelial cells. Am J Physiol Cell Physiol 2012;303:C991999.

59 Closse C, Dachary-Prigent J, Boisseau MR: Phosphatidylserine-related adhesion of human erythrocytes to vascular endothelium. Br J Haematol 1999;107:300-302.

60 Gallagher PG, Chang SH, Rettig MP, Neely JE, Hillery CA, Smith BD, Low PS: Altered erythrocyte endothelial adherence and membrane phospholipid asymmetry in hereditary hydrocytosis. Blood 2003;101:46254627.

61 Pandolfi A, Di Pietro N, Sirolli V, Giardinelli A, Di Silvestre S, Amoroso L, Di Tomo P, Capani F, Consoli A, Bonomini M: Mechanisms of uremic erythrocyte-induced adhesion of human monocytes to cultured endothelial cells. J Cell Physiol 2007;213:699-709.

62 Wood BL, Gibson DF, Tait JF: Increased erythrocyte phosphatidylserine exposure in sickle cell disease: flowcytometric measurement and clinical associations. Blood 1996;88:1873-1880.

63 Abed M, Feger M, Alzoubi K, Pakladok T, Frauenfeld L, Geiger C, Towhid ST, Lang F: Sensitization of erythrocytes to suicidal erythrocyte death following water deprivation. Kidney Blood Press Res 2013;37:567-578.

64 Voelkl J, Alzoubi K, Mamar AK, Ahmed MS, Abed M, Lang F: Stimulation of suicidal erythrocyte death by increased extracellular phosphate concentrations. Kidney Blood Press Res 2013;38:42-51.

65 Abed M, Artunc F, Alzoubi K, Honisch S, Baumann D, Foller M, Lang F: Suicidal erythrocyte death in endstage renal disease. J Mol Med (Berl) 2014;92:871-879.

66 Ahmed MS, Langer H, Abed M, Voelkl J, Lang F: The uremic toxin acrolein promotes suicidal erythrocyte death. Kidney Blood Press Res 2013;37:158-167.

67 Polak-Jonkisz D, Purzyc L: Ca(2+) influx versus efflux during eryptosis in uremic erythrocytes. Blood Purif 2012;34:209-210; author reply 210.

68 Calderon-Salinas JV, Munoz-Reyes EG, Guerrero-Romero JF, Rodriguez-Moran M, Bracho-Riquelme RL, Carrera-Gracia MA, Quintanar-Escorza MA: Eryptosis and oxidative damage in type 2 diabetic mellitus patients with chronic kidney disease. Mol Cell Biochem 2011;357:171-179.

69 Lang PA, Beringer O, Nicolay JP, Amon O, Kempe DS, Hermle T, Attanasio P, Akel A, Schafer R, Friedrich B, Risler T, Baur M, Olbricht CJ, Zimmerhackl LB, Zipfel PF, Wieder T, Lang F: Suicidal death of erythrocytes in recurrent hemolytic uremic syndrome. J Mol Med (Berl) 2006;84:378-388.

70 Nicolay JP, Schneider J, Niemoeller OM, Artunc F, Portero-Otin M, Haik G, Jr., Thornalley PJ, Schleicher E, Wieder T, Lang F: Stimulation of suicidal erythrocyte death by methylglyoxal. Cell Physiol Biochem 2006;18:223-232.

71 Lang E, Gatidis S, Freise NF, Bock H, Kubitz R, Lauermann C, Orth HM, Klindt C, Schuier M, Keitel V, Reich M, Liu G, Schmidt S, Xu HC, Qadri SM, Herebian D, Pandyra AA, Mayatepek E, Gulbins E, Lang F, Haussinger D, Lang KS, Foller M, Lang PA: Conjugated bilirubin triggers anemia by inducing erythrocyte death. Hepatology 2015;61:275-284.

72 Kempe DS, Akel A, Lang PA, Hermle T, Biswas R, Muresanu J, Friedrich B, Dreischer P, Wolz C, Schumacher U, Peschel A, Gotz F, Doring G, Wieder T, Gulbins E, Lang F: Suicidal erythrocyte death in sepsis. J Mol Med (Berl) 2007;85:273-281. 


\section{Cellular Physiology Cell Physiol Biochem 2015;37:2060-2070 \begin{tabular}{l|l|l|l} 
DOI: 10.1159/000438565 & $\begin{array}{l}\text { C } 2015 \text { The Author(s). Published by S. Karger AG, Basel } \\
\text { www.karger.com/cpb }\end{array}$
\end{tabular}}

Egler/Lang: Licochalcone-induced eryptosis

73 Lang PA, Schenck M, Nicolay JP, Becker JU, Kempe DS, Lupescu A, Koka S, Eisele K, Klarl BA, Rubben H, Schmid KW, Mann K, Hildenbrand S, Hefter H, Huber SM, Wieder T, Erhardt A, Haussinger D, Gulbins E, Lang F: Liver cell death and anemia in Wilson disease involve acid sphingomyelinase and ceramide. Nat Med 2007;13:164-170.

74 Jilani K, Lang F: Carmustine-induced phosphatidylserine translocation in the erythrocyte membrane. Toxins (Basel) 2013;5:703-716.

75 Vota DM, Maltaneri RE, Wenker SD, Nesse AB, Vittori DC: Differential erythropoietin action upon cells induced to eryptosis by different agents. Cell Biochem Biophys 2013;65:145-157.

76 Zappulla D: Environmental stress, erythrocyte dysfunctions, inflammation, and the metabolic syndrome: adaptations to CO2 increases? J Cardiometab Syndr 2008;3:30-34.

77 Lupescu A, Jilani K, Zbidah M, Lang F: Patulin-induced suicidal erythrocyte death. Cell Physiol Biochem 2013;32:291-299.

78 Abed M, Zoubi KA, Theurer M, Lang F: Effect of dermaseptin on erythrocytes. Basic Clin Pharmacol Toxicol 2013;113:347-352.

79 Ghashghaeinia M, Cluitmans JC, Toulany M, Saki M, Koberle M, Lang E, Dreischer P, Biedermann T, Duszenko M, Lang F, Bosman GJ, Wieder T: Age Sensitivity of NFkappaB Abundance and Programmed Cell Death in Erythrocytes Induced by NFkappaB Inhibitors. Cell Physiol Biochem 2013;32:801-813.

80 Alzoubi K, Honisch S, Abed M, Lang F: Triggering of Suicidal Erythrocyte Death by Penta-O-galloyl-beta-dglucose. Toxins (Basel) 2014;6:54-65.

81 Jilani K, Enkel S, Bissinger R, Almilaji A, Abed M, Lang F: Fluoxetine induced suicidal erythrocyte death. Toxins (Basel) 2013;5:1230-1243.

82 Lupescu A, Bissinger R, Jilani K, Lang F: Triggering of suicidal erythrocyte death by celecoxib. Toxins (Basel) 2013;5:1543-1554.

83 Arnold M, Lang E, Modicano P, Bissinger R, Faggio C, Abed M, Lang F: Effect of nitazoxanide on erythrocytes. Basic Clin Pharmacol Toxicol 2014;114:421-426.

84 Oswald G, Alzoubi K, Abed M, Lang F: Stimulation of suicidal erythrocyte death by ribavirin. Basic Clin Pharmacol Toxicol 2014;114:311-317.

85 Lupescu A, Bissinger R, Herrmann T, Oswald G, Jilani K, Lang F: Induction of suicidal erythrocyte death by novobiocin. Cell Physiol Biochem 2014;33:670-680.

86 Alzoubi K, Calabròa S, Bissinger R, Abed M, Faggio C, Lang F: Stimulation of Suicidal Erythrocyte Death by Artesunate. Cell Physiol Biochem 2014;34:2232-2244.

87 Arnold M, Bissinger R, Lang F: Mitoxantrone-induced suicidal erythrocyte death. Cell Physiol Biochem 2014;34:1756-1767.

88 Bissinger R, Fischer S, Jilani K, Lang F: Stimulation of Erythrocyte Death by Phloretin. Cell Physiol Biochem 2014;34:2256-2265.

89 Bissinger R, Lupescu A, Zelenak C, Jilani K, Lang F: Stimulation of eryptosis by cryptotanshinone. Cell Physiol Biochem 2014;34:432-442.

90 Bissinger R, Modicano P, Frauenfeld L, Lang E, Jacobi J, Faggio C, Lang F: Estramustine-induced suicidal erythrocyte death. Cell Physiol Biochem 2013;32:1426-1436.

91 Jacobi J, Lang E, Bissinger R, Frauenfeld L, Modicano P, Faggio C, Abed M, Lang F: Stimulation of erythrocyte cell membrane scrambling by mitotane. Cell Physiol Biochem 2014;33:1516-1526.

92 Lupescu A, Bissinger R, Warsi J, Jilani K, Lang F: Stimulation of erythrocyte cell membrane scrambling by gedunin. Cell Physiol Biochem 2014;33:1838-1848.

93 Malik A, Bissinger R, Calabro S, Faggio C, Jilani K, Lang F: Aristolochic Acid Induced Suicidal Erythrocyte Death. Kidney Blood Press Res 2014;39:408-419.

94 Tesoriere L, Attanzio A, Allegra M, Cilla A, Gentile C, Livrea MA: Oxysterol mixture in hypercholesterolemiarelevant proportion causes oxidative stress-dependent eryptosis. Cell Physiol Biochem 2014;34:10751089.

95 Zhang R, Xiang Y, Ran Q, Deng X, Xiao Y, Xiang L, Li Z: Involvement of calcium, reactive oxygen species, and ATP in hexavalent chromium-induced damage in red blood cells. Cell Physiol Biochem 2014;34:1780-1791.

96 Pagano M, Faggio C: The use of erythrocyte fragility to assess xenobiotic cytotoxicity. Cell Biochem Funct 2015;33:351-355. 